Science Life

\title{
ACTIVITIES OF THE LATVIAN ACADEMY OF SCIENCES IN 2016
}

\section{GENERAL MEETINGS OF THE LATVIAN ACADEMY OF SCIENCES IN 2016}

Two General Meetings of the Latvian Academy of Sciences (LAS) were held in 2016.

\section{SPRING GENERAL MEETING, APRIL 7}

The general meeting was attended by Kārlis Šadurskis, Minister of Education and Science, Jānis Vucāns, member of Saeima Education, Culture, and Science Committee, LAS members, Academy of Sciences award recipients, and guests of the meeting. State President Raimonds Vejonis sent a message of greetings to the participants.

An introductory address was given by the LAS president Ojārs Spārītis, the Education and Science Minister Kārlis Šadurskis delivered a speech to the General Meeting expressing his gratitude for the past and future contribution of scientists to the country, and presented the action plan outlining the prospects of increase of funding for education and science from the state budget. The LAS prizes and awards for young scientists were distributed. The report on the LAS activities in 2015 was given by the LAS Secretary General Valdis Kampars. The Chairman of the Supervisory Council Juris Krūminšr read the Supervisory Council report on the LAS 2015 operation supervision, concluding that no serious shortcomings had been identified and wishing success in the LAS lawsuit against "Rìgas koncertzāle" (Riga Concert Hall). The General Meeting approved both reports. The LAS presidential candidate Ojārs Spārītis gave the Academy members a presentation on his work and his new team's plans for the next four-year period. The LAS presidential and officials' elections followed. Academicians Baiba Rivža, Andris Šternbergs, Dace Markus, and Dr.h.c.sc.comp. Edvīns Karnītis took part in the debate while the votes were counted.

LAS Full Member Ojārs Spārītis was re-elected as the LAS President, and LAS full members Andrejs Ërglis and Andrejs Krasnikovs - as Vice Presidents. LAS Full Member Andrejs Siliņ̌̌ was elected as the LAS Secretary General, and LAS Full Member Tālavs Jundzis — as the Foreign Secretary. Academician Bruno Andersons was elected as the Chairman of the LAS Foundation. The newly elected Supervisory Council comprises LAS full members Juris Krūmiņš, Ārija Meikališa, Edīte Kaufmane, Jurijs Dehtjars, Andris Ozols, İzaks Rašals, Nikolajs Sjakste. The General Meeting approved the elected chairs of LAS divisions: LAS Full Member Raita Karnite - the Division of Social Sciences and Humanities; LAS Full Member Baiba Rivža the Division of Agriculture and Forestry Sciences; LAS Full Member Jānis Spīgulis - the Division of Physical and Technical Sciences; LAS Corresponding Member Pēteris Trapencieris - the Division of Chemical, Biological, and Medical Sciences. The elected LAS Senate members are LAS full members Mārcis Auziñš, Ilga Jansone, Ivars Kalviņš, Jānis Kloviņš, Maija Kūle, Dace Markus, Indriḳis Muižnieks, Modra Murovska, İzaks Rašals, Leonīds Ribickis, Jānis Stradiņš, Andris Šternbergs, Guntis Zemītis, and in advisory capacity — LAS corresponding members Juris Borzovs and Tatjana Koke.

\section{AUTUMN GENERAL MEETING, NOVEMBER 24}

President Ojārs Spārītis spoke the introductory words. The General Meeting was also addressed by Jānis Vucāns, Chairman of Saeima Budget and Finance Committee, and Jānis Endziṇš, Chairman of the Board of the Latvian Chamber of Commerce and Industry, who urged the scientists to take part in EXPO 2017, whose theme is "Future Energy", in Kazakhstan, Astana, if they have scientific achievements that can be commercialised.

Traditionally the LAS Autumn General Meeting is dedicated to honouring the recipients of the LAS Grand Medal. This year, the Grand Medal was awarded to LAS Full Member Tālavs Jundzis for his studies in the history of Latvian independence restoration, and to Professor Dr.habil.med. Romans Lācis for an important contribution to the development of cardiac surgery in Latvia. Laudatio for Tālavs Jundzis was spoken by LAS Full Member Jānis Stradiņš, Laudatio for Romāns Lācis in video version was spoken by Andrejs Ërglis (see LAS website). T. Jundzis delivered an academic lecture "Continuity doctrine in the restoration of Latvian independence from 1986 to 1991", whereas R. Lācis gave an emotional academic lecture "What is the heart" (see pp. 81-83 of this issue, "Soul. Heart. Surgery"). 
The election of new LAS members was held during the meeting. The elected full members were Ina Druviete (linguistics), Donāts Erts (physics), Aleksejs Kuzmins (physics), Remigijs Počs (economy), Uldis Rogulis (physics), Inna Šteinbuka (economy), and Pēteris Trapencieris (chemistry).

The newly elected corresponding members of the LAS included Ivars Austers (psychology), Uǵis Cābulis (forestry science), Ēriks Jēkabsons (history), Sandra MuižnieceBrasava (agricultural science), Aiva Plotniece (chemistry), Gita Rēvalde (astronomy), and Andris Zeltiņš (biology).

Four foreign members were elected: Zenon Dabkevičius (agricultural science, Lithuania), Vladimirs Gevorgjans (chemistry, USA), Viktoras Algirdas Sniečkus (chemistry, Canada), and Jānis Vārna (mechanics, Sweden).

The Latvian Academy of Sciences acquired two new Honorary Members — composer Mārtiņš Brauns and musicologist Arnolds Laimonis Klotiņš.

\section{ACTIVITIES OF THE ACADEMY'S SCIEN- TIFIC DIVISIONS ASSOCIATED WITH NAT- URAL SCIENCES IN 2016}

\section{ACTIVITIES OF THE DIVISION OF PHYSICS AND TECHNICAL SCIENCES}

The Department of Physics and Technical Sciences (DPTS) joins 106 LAS members, including 41 full members, 3 honorary members, 26 foreign members, 35 corresponding members, and 17 doctors honoris causa.

In 2016, the Division experienced essential changes. The following Academy members passed away: the former president of the LAS (2004-2012), Chairman of the Division (1991-2004) LAS Full Member Juris Ekmanis, Chairman of the Division (2004-2016) LAS Full Member Juris Jansons, a prominent Latvian computer scientist and mathematician, winner of the LAS Grand Medal LAS Full Member Rūsiņš Mārtiņš Freivalds, an outstanding expert in power engineering, LAS Honorary Member Viktors Zēbergs, and two foreign members of the LAS - an outstanding engineer from Sweden Ralejs Tepfers and an outstanding mechanics scientist from the USA Jānis Dundurs. The new Chairman of the Division, LAS Full Member Jānis Spīgulis, Vice-chairman, LAS Full Member Andris Ozols, and the new Council started work in the Division. The LAS foreign members Antonio Biankoni, Robert Evarestov, Juris Upatnieks, Dainis Dravin̄š, Pauls Stradiṇš, Jānis Vārna, and Tarmo Soomere were involved in the activities of the Division.

In 2016, 11 meetings of the Division were held, including the traditional extended joint meetings with Latvian specialists in power engineering. Members of the Division have or- ganised five popular-scientific meetings (three of the LAS and two of the DPTS) and actively participated in the general meetings of the LAS and other events.

\section{Meetings}

27 January - meeting-discussion "Oscillations of Neutrino. From the Origins to the Nobel Prize in 2015", organised by LAS Full Member Oḷǵgerts Dumbrājs.

28 January - emergency meeting, where LAS Full Member Māris Knite was released from his duties as Vicechairman of the Division and two candidates - LAS full members Jānis Spīgulis and Andris Ozols - were nominated to the election of the Chairman on 2 March. It was decided that during the illness of J. Jansons, at the meetings of LAS Presidium and Senate, the Chairman of the Division would be substituted by A. Ozols or J. Spīgulis. Looking forward to the LAS General Meeting on 7 April, Ojārs Spārītis was nominated as a candidate to the position of the LAS President.

2 March - full meeting of the DPTS. Members of the Division discussed the report on Division's activities in 2015, acknowledged it and accepted the proposals for the Division's activities in 2016. In blind election, LAS Full Member Jānis Spīgulis was appointed as Chairman of the Division. LAS full members Andris Šternbergs, Leonīds Ribickis, Mārcis Auziņš and LAS Corresponding Member Juris Borzovs were nominated as members of the LAS Senate.

27 April - meeting with the report delivered by the NASA scientist Ilmārs Dālinšs, "Earth Superficial Convulsions, Initiated by Powerful Rocket Actions". The speaker shared his research experience in the USA and Canada, including collaboration with the legendary rocket designer Wernher von Braun.

24 May - traditional out-meeting at the Institute of Solid State Physics with presentation of LAS Foreign Member Pauls Stradiňš, "Photovoltaics: Global Perspective and Highly Efficient Silicon PV". He is a researcher at the National Renewable Energy Laboratory, USA, and a professor at Colorado School of Mines. Current state-of-the-art and the development trends of photovoltaics were described, as well as physical phenomena driving the operation of silicon photovoltaic elements. One of the main conclusions was: non-organic photovoltaic elements are more promising if compared with the organic ones, as the latter face problems of aging and durability.

30 August - Chairman of the Division Jānis Spīgulis informed about the challenges and plans of the Division for the years 2016-2017. Andris Ozols was elected as Vicechairman of the DPTS, and the following Council members were elected: Donāts Erts, Modris Greitāns, Vjačeslavs Kasčejevs, Māris Knite, Andrejs Krasņikovs, Mārtiņš Rutkis, and Juris Žagars. LAS Honorary Member Namejs Zeltiņš reminded that the LAS is a corporate member of the 
National Committee of World Energy Council, and invited the members of DPTS to participate in a study and to fill the questionnaires related to energy monitoring. Latvian data will be compared to the global and European data in order to specify the expert calculations and decisions.

28 September - Director of the Institute of Physical Energetics (IPE) Dr.sc.eng. I. Oḷeinikova reported on "IPE Development 2020+: Smart Energy, Smart Materials, Technologies and Engineering Systems". She informed on the LAS and IPE activities, the achieved results, research priorities corresponding the Smart Specialization Strategy of Latvia and the gaining of external finances in order to reach the planned goals. IPE development strategy envisages special attention to creation of stronger ties between research and innovation, based on the already existing collaboration with industry and attracting new industrial partners. IPE performs complex studies in the field of power industry that are important for Latvia's policies of climate, environmental protection, power engineering, and the research strategy proposes to further develop them in future. Department members voted to support retaining IPE as an independent State research institute.

5 October - two presentations by LAS member candidates: Dr.phys. Aleksejs Kuzmins, leading researcher of the Institute of Solid State Physics (ISSP), University of Latvia (UL), reported on "Contemporary X-ray Absorption Spectroscopy - When Theory Meets Experiment"; and Dr.habil.phys. Uldis Rogulis, head of the laboratory at ISSP and professor at the UL, reported on "Optically Detectable Magnetic Resonance Spectroscopy in Crystals, Glasses and Glass Ceramics". LAS Vice-president, LAS Full Member A. Krasnikovs informed about research achievements of the candidate to LAS Foreign Member, professor of Lulea Technical University (Sweden) $P h D$ Jānis Vārna and his collaboration with Latvia.

12 October - two more presentations of LAS member candidates: Dr.chem. Donāts Erts, Director of the Institute of Chemical Physics and associated professor at the UL, and Dr.phys. Gita Rēvalde, leading researcher of the Smart Technology Centre, Ventspils University College, and associated professor of Riga Technical University. After the discussion, blind voting on all LAS member candidates took place.

9 November - joint meeting with the Division of the $\mathrm{Hu}-$ manities and Social Sciences, "Problems and Solutions of Machine Translation". LAS Doctor honoris causa, Dr.philol. Sarma Kl,avin,a reported on "Mathematical, quantitative, and computer linguistics in Latvia, 1960s-1990s". After her presentation, the young scientists Dr.sc.comp. Inguna Skadin,a, Dr.sc.comp. Normunds Grūzītis, Dr.sc.comp. Raivis Skadiņš, and Dr.sc.comp. Andrejs Vasiljevs continued with a joint presentation "Latvian Language in the Digital Era - From Investigations to Applications". The conclusion was that Latvian language is not under immediate danger, but the situation can change radically if the new technologies efficiently adapt human languages.
Condition for survival of a language (even with a small number of speakers) will be wide access to language technology solutions of acceptable quality. Therefore, investments in the field of state language technologies are necessary.

24 November - LAS Autumn General Meeting elected three new LAS full members - Donāts Erts, Aleksejs Kuzmins, and Uldis Rogulis, as well as LAS Corresponding Member Gita Rēvalde and LAS Foreign Member Jānis Vārna.

2 December - extended meeting of the Division and the Latvian National Committee of the World Energy Council, in memory of the LAS President (2004-2012) Juris Ekmanis and dedicated to his $75^{\text {th }}$ anniversary. His widow Astrīda Ekmane participated at this meeting.

\section{LAS meetings}

19 January - authors of the most outstanding scientific achievements of the year 2015 were celebrated and awarded in the Portrait Hall of the LAS. Among the laureates, there were three academicians of the Division - Mārcis Auziņš, Ruvins Ferbers, and Juris Purāns, along with their PhD students. As usually, this event gained wide attention of the mass media.

20 January - lecture of the LAS Foreign Member of the Division, Professor Antonio Bianconi, "From Quantum Complex Matter to Quantum Biology: The Emergence of a New Physics in the XXI Century", in the Portrait Hall of the LAS.

26 May - awarding ceremony of the Eižens Āriņš prize in computer science 2016. Dr.h.c. Valdis Lokenbahs, one of the IT pioneers in Latvia, received this prize for significant practical input in the development of computer science in the country. He has created hundreds of IT job positions in Latvia and by his professional activities has promoted development of IT export from Latvia, as well as has been a founder of several significant IT organisations (LIKTA, RITI). A Certificate of Appreciation was granted to Professor of Riga Technical University, LAS Full Member Jurijs Merkurjevs under whose guidance efficient solutions in applied modelling and simulation technologies have been elaborated, as well as integrated simulations with industrial applications.

16 September - archives of the psychologist and pedagogue Eleonora Upatniece (1893-1980) was ceremonially handed to the Academic Library of the University of Latvia. Her son, LAS Foreign Member Juris Upatnieks participated with an address.

21 September - traditional LAS meeting-discussion, moderated by the laureate of LAS Grand Medal, LAS Full Member Kurts Švarcs — "Light: Euclide, Einstein and quantum computers". 
4 October - joint event of the LAS and the journal Zvaigžnotā Debess (The Starry Sky), "Zvaigžnotā Debess joins Latvia and the world". Reports were delivered by astronomers - authors of the journal: LAS Foreign Member, professor of Lund Observatory (Sweden) Dainis Draviñ̌s and $P h D$ Andris Slavinskis, Head of Space Technology Department of the Tartu Observatory (Estonia).

\section{ACTIVITIES OF THE DIVISION OF CHEMICAL, BIO- LOGICAL AND MEDICAL SCIENCES}

The Division unites 121 members, among them 45 full, 2 honorary, 30 foreign, and 44 corresponding members, and 24 Doctors honoris causa.

In 2016, nine (9) meetings of the Division of Chemical, Biological, and Medical Sciences (DCBMS) were held.

5 February - extended meeting of the LAS Division of Chemical, Biological, and Medical Sciences, together with the Institute for Breath Research, University of Innsbruck, the University of Latvia, the Latvian Institute of Organic Synthesis (LIOS), the LU Institute of Solid State Physics, and the Riga East Clinical University Hospital in connection with the Sniffphone project "The analysis of volatile bonds in medicine, metabolemics". The meeting was chaired by Dāvids Frīdmans and Ilva Nakurte, opening remarks were made by LAS Full Member Raimonds Valters. Six reports were presented: by LAS Corresponding Member Līga Grīnberga, Dr.phys. Jānis Kleperis, "Electronic Nose and Gas Analysis Systems - Research and Applications at ISSP UL and Rīga"; LAS Corresponding Member Mārcis Leja, "The Principles of Volatile Marker Diagnostics Research. Research of Digestive System Tumours"; Immanuels Taivans, "The Analysis of Exhaled Air Using Gas Chromotography and Artificial Smell Sensors in Diagnosis of Lung Cancer"; Pawel Mochalski, Alex Schmid, "Analysis of Human Volatolome: a New Potential Tool for Medicine, Toxicology and Safety and Security Applications"; LAS Corresponding Member Osvalds Pugovičs, "Metabolomics - Magic Wand or Tailor-made Analysis"; LAS Full Member Nikolajs Sjakste, "How to Create a Link Between Genomics and Proteomics"

12 February - general meeting of the Division of Chemical, Biological, and Medical Sciences. LAS Full Member Raimonds Valters presented an overview of Division's activities in 2015 and LAS Corresponding Member Edgars Liepiňš presented a lecture on "The Metabolism of Energy: Health, Food and Physical Activity". A new Chair of the DCBMS was elected. LAS Full Member Raimonds Valters nominated LAS Corresponding Member Pēteris Trapencieris and the Division, voting by secret ballot, confirmed P. Trapencieris as the Chair of the DCBMS.

26 February - extended meeting of the Division of Chemical, Biological, and Medical Sciences as part of the lecture series "The most significant achievements in Latvian science in 2015" together with the University of Latvia,
Riga East Clinical University Hospital, and Digestive Disorders Centre GASTRO, on the topic "Research of Malignant Tumour Prevention and Screening in Latvia" (Chair LAS Corresponding Member, Prof. Mārcis Leja). Seven reports were presented: LAS Corresponding Member Mārcis Leja, "Stomach and Intestine Cancer Prevention Study GISTAR - achievements and prospects"; $D r$. P. Krike "Biomarker Research in the Identification of Stomach Cancer Risk"; Dr. R. Škapars, "Volatile Marker Research"; Assoc. Professor. I. Daugule, "Research into the Main Cause of Stomach Cancer, H.pylori"; Dr. I. Kikuste, "The Use of Modern Endoscopic Systems in Early Stomach Disorder Diagnostics"; Dr. S. Isajevs, "Pathology in Stratification of Pre-cancer Conditions and Cancer Risk", and Dr. D. Šantare, "Intestine Cancer Screening Pilot Research in Latvia".

The GISTAR study researches the prevention of digestive tract (stomach cancer, intestine cancer) tumours and is the only one of its kind in Europe. 3360 inhabitants of Cēsis, Alūksne, Ludza, and Saldus took part in the study. The goal of the study is to decrease tumour-induced mortality by testing familiar opportunities and seeking for new ones. After a successful completion of the pilot study, it is planned to start the main research involving 30000 individuals both in Latvia and abroad. The existing methods for early tumour diagnosis are analysed and new methods are sought for.

Plans are to focus a lot of attention on microbiom research, because it is significantly affected by the use of antibiotics. Considering the aforementioned, a series of studies has been done as part of GISTAR. This work has been done in collaboration with the Latvian Biomedicine Research and Study Centre (LBRSC), Digestive Disorders Centre GASTRO, the Academic Histology Laboratory, and Riga East Clinical University Hospital (tumour autoantisubstance research, biomarker research, stomach cancer risk stratification research). In genetic research our main collaborative partners have been the Health Sciences University of Lithuania (Kaunas, Lithuania) and Magdeburg University (Germany). Significant work in volatile marker research has been done in collaboration with the Israel Technology Institute TECHNION (Haifa, Israel), Madrid University in Spain as well as many other partners within the Sniffphone project. In the field of microbiome research successful collaboration has been maintained with Karolinska University and the LBRSC. Considering future plans to open potential new centres, collaboration has been established with institutions in Belarus, Ukraine, Russia, and Kazakhstan.

The participants of the general meeting of the DCBMS expressed their appreciation and gratitude to Professor Mārcis Leja for his successful project leadership and ability to involve many specialists and productive collaboration with foreign colleagues.

Additional information about the GISTAR project is available at www.gistar.eu 
18 March - a meeting continuing the discussion of the most significant scientific achievements of 2015, together with the University of Latvia, Riga East Clinical University Hospital, and the Digestive Disorders Center GASTRO. Two reports on the topic were presented, "New Catalytic Processes in the Conversion of Biomass in Fuels" (Head Researcher LAS Full Member V. Kampars): Dr.chem. Kristaps Māliņ̌̌ "Development of New Catalytic Processes in the Conversion of Biomass in Fuels" and Mg.chem. Kristīne Lazdoviča, "Catalytic Pyrolysis".

The research was conducted at the Applied Chemistry Institute of the Faculty of the Materials Science and Applied Chemistry, Riga Technical University. The reports presented detailed information about the research of first-generation biofuel production using local natural resources rapeseed oil and fatty acids and second generation biofuel (hydrocarbons) and research of the production using local biomass (biooil).

Another achievement of 2015 presented at this meeting was LAS Corresponding Member Pāvels Arsenjans' report "The Original Anti-cancer Drug Candidates Containing Selenium". Dr.chem. P. Arsenjans' group has developed a methodological guarantee for the synthesis of selenium-containing heterocycles. This has allowed the discovery of new chemical substances showing interesting biological characteristics and demonstrate the special role of selenium in the human organism.

The chairman of LAS Division of Chemical, Biological, and Medical Sciences LAS Full Member Raimonds Valters informed the meeting that at the LAS Spring General Meeting, on 7 April, elections for the post of the LAS President and for LAS Senate would take place. The Division had to nominate five candidates for the Senate from its membership. The following candidates were proposed: LAS Full Member Ivars Kalviņš, LAS Full Member Jānis Klovin̄š, LAS Full Member Indrikis Muižnieks, LAS Full Member. Modra Murovska, LAS Full Member Jānis Stradiņš. Voting openly the Division members expressed their support for all the candidates to the LAS Senate.

15 April - as he opened the Division meeting, LAS Full Member Raimonds Valters asked for a moment of silence in honour of the late Juris Ekmanis (1941-2016) who was president of LAS from 2004 to 2012. The meeting continued with a look at the nominated works for "Significant achievements in Latvian science in 2015" that had not received awards. The nomination from the University of Latvia in the field of applied science was the work "Research of organic substances (humic substances) of natural origin, their practical application and production" (head researcher LAS Full Member Māris Kḷaviṇš).

Studies of humic substances that have been performed by the University of Latvia since 1993 are a significant internationally recognised direction of research aimed at the use of the natural resources of Latvia and seeking their new applications. The research has reached significant scientific and applied results and deserved to be named as the applied science achievement of 2015.

Six reports were presented on research of peat, sedimentation, and their uses: Ingrīda Krīgere, Director of the Peat Producers Association of Latvia, "Peat Bogs, Peat Harvestation and Its Use in Latvia and Europe"; LAS Full Member Māris Kḷaviņš, "Research on Bogs and Peat: Potential Value and Innovation"; Dr.geogr. Laimdota Kalnina, "Investigation of Latvia's Bogs: History, the Present and the Future"; Dr.geogr. Oskars Purmalis, "Humic Substance Characteristics of Peat"; Dr.geogr. Jānis Krūmiņš, "Lowland Bog Peat and Its Possible Application"; $M g$. Karīna Stankeviča, "Sedimentation: Practical Significance and Prevalence in Latvia".

The LAS CBMS participants expressed their gratitude and appreciation to LAS Full Member Māris Kḷaviņš for the well-prepared reports about these significant investigation results in Latvia and for involving investigators of this research themselves in the presentations.

7 September - in his opening remarks the new Chair of the DCBMS Corresponding Member Pēteris Trapencieris thanked LAS Full Member Raimonds Valters and scientific secretary Dr.chem. Baiba Ādamsone for their excellent leadership of the DCBMS and organisation of scientific activities.

On the agenda for the meeting was the lecture by Dr.habil.biol. Dmitrijs Babarikins on "Food Supplements and Human Health. A Vision of Future Innovations". Co-author LAS Full Member Dr.habil.biol. Rafails Rozentāls supplemented the lecture with his comments. Following the lively debates participants expressed their gratitude to the author for the extensive information about significant research of food supplements.

Then the Chair of the Division LAS Corresponding Member Pēteris Trapencieris presented the action plans for 2016-2017: CBMS meetings would adhere to the present thematic lecture format, but inviting more foreign member to participate, discussions involving representatives of various public organisations were planned, and all award recipients would be given the opportunity to present their work at Division meetings. Scientists were encouraged to take part in different activities in Latvia and Europe and actively participate in work groups. The topics for upcoming meetings include: "Experimental Use of Animals in Pharmacology and Biology Research" (LAS Full Member N. Sjakste), "Granting Procedures" (LAS Full Member J. Ërenpreisa).

13 October - two LAS corresponding members' reviews about scientific, pedagogical, and organisational activities: Dr.sc. ing. Dagnija Loča, Director of the Riga Technical University (RTU), Rūdolfs Cimdiňš, Riga Centre for Biomaterial Innovation and Development, Lead Investigator, "Biomaterials Containing Calcium Phosphates -Engineering of Bone Implants or a Tool for Active Local Substance Supply?"; and Dr.chem. Aiva Plotniece, Lead 
Investigator at the Laboratory of the Membrane-active Compounds and $\beta$-diketones, LIOS, "Synthetic Lipids as Prospective Drug Transport Forms in Nanoscience".

LAS Full Member Maija Dambrova expressed her approval of the scientific work of both Dagnija Loča and Aiva Plotniece who received L'Oreal scholarships showing that the candidates are among the leading respected natural science investigators in Latvia. LAS Full Member Ivars Kalvin̄š pointed out that both Dagnija Loča and Aiva Plotniece have a successful collaboration with LIOS: it is now possible to pursue new scientific directions so that experiments in chemistry can move on to experiments of nanostructures, biology, and genes, thus merging several areas of science. LAS Full Member Gunārs Duburs noted Aiva Plotniece's growth from a timid student into a responsible scientist, and LAS Full Member Ruta Muceniece characterised Aiva Plotniece as an erudite scientist with a broad range of scientific interests: $40 \%$ chemistry, $60 \%$ other areas of science. Her work had started with experiments in melanocortin receptors made in Uppsala and Prof. Muceniece recommended Aiva Plotniece as a candidate for LAS corresponding member; LAS Corresponding Member Pēteris Trapencieris characterised both applicants as high-class professionals, excellent individuals, meeting all the criteria to be elected as LAS corresponding members. Unfortunately, there was only one corresponding member vacancy in material sciences in 2016.

Voting by secret ballot the members of the DCBMS voted to support both Dagnija Loča and Aiva Plotniece as candidates for LAS corresponding member LAS status.

27 October - member candidates of the LAS presented their overviews of scientific, pedagogical, and organisational activities: candidate for the status of LAS corresponding member Dr.biol. Andris Zeltiňš, Head and leading investigator of the Plant Virology Group, LBRSC, "Plant Viruses in Recombinant Biotechnology" and candidate for LAS full member Pēteris Trapencieris, Head and leading investigator of the Laboratory of Chemistry, Latvian Institute of Organic Synthesis, "Dual Inhibitors in the Design of Anti-cancer Drugs".

LAS Full Member Elmārs Grēns expressed support for Andris Zeltiňš whom he characterised as independent and self-reliant, precise and fast worker, whose scientific work is original in its development of complex methodology since plant viruses differ from other viruses. One might say that there is a rebirth of recombinant virus research in Latvia. LAS Full Member Jānis Klovin̄š recommended Andris Zeltiņš, according to him, Andris Zeltiņš' results are always $100 \%$ verified. At first he conducted basic experiments followed by more modern methods and potential application of in-depth research.

LAS Full Member Ivars Kalvin̄š characterised Pēteris Trapencieris as a good specialist and Head of the LIOS Organic Chemistry Laboratory who has acquired considerable experience outside Latvia (Germany, France, the USA). In his scientific work he develops modifications of natural materials that have the potential of becoming medicines. Pēteris Trapencieris has been a lecturer since 1995 and has organised creative and informative conferences - the Paul Walden symposia in organic chemistry and the Balticum Organicum Syntheticum (BOS) conferences in Latvia. I. Kalviņš went on to recommend Trapencieris as an erudite scientist with broad scientific interests and good organisational skills who is able to attract people and achieve collaboration between young students and experienced researchers on a local and international level. LAS Full Member Raimonds Valters proposed that the DCBMS scientists vote for Pēteris Trapencieris as LAS full member.

LAS Corresponding Member Pēteris Trapencieris shared information about LAS foreign member candidates Professor Viktors Sniečkus from Queens University in Canada and Professor Vladimir Gevorgyan. This year at the ninth Balticum Organicum Syntheticum conference in Riga President of the LAS Ojārs Spārītis had expressed surprise that Viktors Sniečkus was not yet a LAS foreign member and recommended that he be elected this year. In 2000, Viktors Sniečkus initiated the organisation of a new-format chemists' conference in the Baltic States, the BOS. The second BOS conference took place in Vilnius and since then they alternate on a regular basis between Latvia, Estonia, and Lithuania. In October 2003, Viktors Sniečkus was present at the unveiling of the monument in honour of Paul Walden. Thanks to Professor Viktors Sniečkus and LAS Foreign Member Professor Edvīns Vedējs, BOS-format conferences have become very significant in the development of Latvia's chemists. In his motivational words to BOS lecturers Professor Sniečkus once said: "One of the prerequisites to receiving the Nobel Prize is to be a BOS lecturer". These words became reality earlier this year, since organic chemist Ben Feringa from the Netherlands, who received the Nobel Prize in chemistry in 2016, was a lecturer at the BOS conference in Vilnius in 2008. LAS Full Member Ivars Kalvin̄š noted that since 2000 the activities of Professor Sniečkus have helped raise the level of Baltic scientists and brought them world-wide recognition. He was also instrumental in establishing contacts with scientists abroad.

LAS Full Member Māris Turks recommended LAS Foreign Member Professor Vladimir Gevorgyan at Chicago characterising him as an erudite, internationally well-known scientist who excels in various areas of organic chemistry and assists the editorial staff of the journal Chemistry of Heterocyclic Compounds. The role of Professor Gevorgyan in raising the journal's impact factor is invaluable. LAS Corresponding Member Pēteris Trapencieris briefly commented Professor Gevorgyan's work at the Latvian Institute of Organic Synthesis in the late 1980s and several of his projects at scientific institutes and universities in Japan, Italy, and the US.

In a secret ballot vote the DCBMS members stated their support to the following candidates: Andris Zeltiņš for election as LAS corresponding member, Pēteris Trapencieris - 
as LAS Full Member, and Viktors Sniečkus and Vladimir Gevorgyan — as LAS foreign members.

19 December - the open meeting of the DCBMS took place at the Latvian Institute of Organic Synthesis with the main point on the agenda being the lecture by LAS Foreign Member, Professor Vladimir Gevorgyan (University of Illinois at Chicago, USA) on the "Development of Novel Synthetic Methodologies".

LAS Corresponding Member Pēteris Trapencieris gave an overview of Professor Gevorgyan's early career at the Latvian Institute of Organic Synthesis in the 1980s starting with his Doctoral studies there. Several ideas that he developed while working in Japan were adapted to the experimental needs of our chemists in the 1990s, for example, work with thin layer chromotography plates significantly reduced in size. After his studies in the USA, young scientists in Latvia started to join his group in 2004. The first two to present their doctoral theses were two young LIOS scientists - Natālija Čerņaka (2010) and Dmitrijs Čerņaks (2011). Following his post-doctoral studies, Dmitrijs Černaks returned to work in Latvia.

The members of the Division expressed their appreciation and gratitude to Professor Gevorgyan for his contribution to the professional development and growth of Latvia's young chemists as well as for his active involvement in the editorial work at the journal Chemistry of Heterocyclic Compounds and wished him continuing success in the collaboration of the University of Illinois at Chicago with LIOS and LAS.

\section{DIVISION OF AGRICULTURE AND FORESTRY SCI- ENCES}

The Division unites 33 members of the Latvian Academy of Sciences (LAS), including 9 full members, 2 honorary members, 3 foreign members, and 19 corresponding members. One LAS Doctor honoris causa is involved in the Division's activities.

The Division's activities were organised based on a letter of intent signed on 17 February 2016 among the Latvian Academy of Sciences (hereinafter the LAS), the Latvian Academy of Agricultural and Forestry Sciences (hereinafter the LAAFS), and the Ministry of Agriculture (hereinafter the MoA).

The letter of intent provides for cooperation in the exchange of information on higher education and science matters among the MoA, the LAS, and the LAAFS; cooperation in the development of recommendations for policy makers regarding enhancements in higher education and science, including activities aimed at increasing the international competitiveness of scientific institutions as well as closer cooperation with industry; joint organisation of conferences, expositions, and other events aimed at popularising scientific achievements; cooperation in the preparation of new scientists in the fields the MoA is responsible for; coopera- tion in the organisation of young scientist contests in agricultural sciences; cooperation in providing assistance in the organisation of the harvest festival "Vecauce - 2016"; cooperation in evaluating scientific works submitted to the contest "Sējējs" (Sower) of the MoA in the section "Science for Rural Development"; international cooperation and cooperation in holding annual surveys of institutes of agricultural and forestry sciences.

In 2016, the LAS Division of Agricultural and Forestry Sciences cooperated with the MoA of the Republic of Latvia, the Latvian Academy of Agricultural and Forestry Sciences, the Council of Directors of Latvian Scientific Agricultural Institutions (CDLSAI), the Latvian Agricultural Organisation Cooperation Council (LAOCC), the Nordic Association of Agricultural Scientists, the Union of European Academies for Sciences applied to Agriculture, Food and Nature (UEAA) and other institutions.

\section{The most important activities}

25 January - a joint meeting of the LAS DAFS and the LAAFS presidium. A winner of the Top 10 Scientific Achievements 2015, Dr.sc.ing. Ilga Gedrovica, reported at the meeting, explaining the way made by a product from its development at a laboratory to a well-known brand. Ilga Gedrovica familiarised the participants with the products: "Milzu!", "BEE BITE" and "Garden Snack", which were developed in cooperation with entrepreneurs and the LUA Technology and Knowledge Transfer Department. LAS Full Member Baiba Rivža acquainted the participants with the activities of the LAS Division of Agricultural and Forestry Sciences and the Latvian Academy of Agricultural and Forestry Sciences in 2015, about the work done within the research project ERANET SUMFOREST and the thematic project of the Swedish Institute "ICE - Innovation Creativity Equality". She also informed the participants that a new research project "Data Driven Dairy Decisions for Farmers" (4D4F) focusing on dairy farms would be started in April. Latvia is going to participate in the project as a partner country and work on data collection and processing, and to ensure that the project's results are introduced in dairy farms of Latvia.

29 February - a joint meeting of the LAS DAFS and the LAAFS presidium. Dr.habil.chem. Galina Teliševa, a winner of the Top 10 Scientific Achievements 2015 reported at the meeting. The scientist familiarised the participants with an innovative process developed at the Latvian State Institute of Wood Chemistry, which involved the pre-processing of plant biomass granules in a microwave field and a further modification of their surface by means of oils of natural origin or used oil products, thereby considerably increasing the energy value of granulated plant biomass and enhancing other consumption characteristics. The agenda of the meeting included voting to express support to the chairwoman of the Division and the nomination of a candidate to the president of the Latvian Academy of Sciences. LAS Full Member Baiba Rivža was nominated as a candidate to the head 
of the Division by secret ballot. At the meeting, unanimous support was expressed to the current president of the Latvian Academy of Sciences, LAS Full Member Ojārs Spārītis, to continue the work started. The LAS president familiarised the participants with his vision of the further activity of the LAS and the role of the LAS Division of Agricultural and Forestry Sciences in uniting agricultural scientists. The LAS president informed the audience about a call and initiative of the Latvian Chamber of Commerce and Industry (LCCI) to hold an exposition of products being at the stage of development in cooperation with the LAS DAFS aimed at potentially commercialising the products in future.

15 April - the first contact exchange "The Scientist Meets the Entrepreneur" was held for entrepreneurs and agricultural scientists at the hall of the LCCI, which was organised as an offsite meeting of the Division. In their presentations and conversations, the agricultural scientists familiarised the entrepreneurs with the new technologies, crop varieties, and food processing processes developed at their institutes as well as the products already being on the market. The presentations were made to entrepreneurs who might be potentially interested in introducing the products or technologies in production. LAS Full Member Baiba Rivža acquainted the audience with representatives of LUA institutes. The academician also talked about the consolidation of agricultural research institutions and the large role of Latvia University of Agriculture in raising the scientific capacity of the institutions.

Opportunities for the LUA Technology and Knowledge Transfer Department were presented by its head, Dr.sc.ing. Sandra Muižniece-Brasava. As part of cooperation, scientists can offer entrepreneurs to perform theoretical and practical research studies in such sciences or fields as food, forestry, multifunctional agriculture, electrical power, information technologies, sustainable rural development, etc.

The director of the LUA Institute of Horticulture, Mg.oec., Mg.sc.soc. Inese Ebele, reported that the institute currently actively cooperated with entrepreneurs, and it was due to the active research work done by LAS Corresponding Member Dr.biol. Edīte Kaufmane, LAS Corresponding Member Dr.sc.ing. Dalija Seglina, and other scientists of the Institute. Cooperation between entrepreneurs and the Institute has yielded already now well-known brand products: juices "Verry Berry", candied fruits "Rāmkalni", a series of vitamin-rich products "Mežrozītes.lv", and other products. The Institute of Agrocultural Resources and Economics which was represented by Dr.agr. Arta Kronberga and LAS Corresponding Member Dr.agr. Ilze Skrabule, focused on two priorities: breeding of high quality varieties of cereals and development of related products, breeding of varieties of legumes and potatoes, and development of related products. The Institute bred and grew varieties of husk-free barley, wheat and oats, the advantage of which was a possibility to harvest "pure grains" that could be processed into flakes or flour without doing a mechanical husking operation. A leading researcher of the LLU Research Centre
Ulbroka, Dr.sc.ing Ādolfs Ruciňš, reported on the centre's cooperation with the Institute of Physical Energetics. The scientists have jointly developed and patented a technology that allows producing $100 \%$ bioethanol. The new technology allows saving energy up to $70 \%$ and ensures a continuous bioethanol production process. In view of the fact that Latvia introduced a 5\% mandatory admixture of bioethanol to A95 petrol sold at petrol stations in Latvia, this could result in several million EUR savings per year.

2 May - a joint meeting of the LAS DAFS and the LAAFS presidium, in which various organisational issues were discussed in respect to the general meeting of the Division to be held on 10 June and the election of new LAAFS members. The chairman of the executive board of the CDLSAI, Mg.agr. Ģedimins Siliņš, introduced the participants to a plan regarding holding an exposition of field and laboratory experiments in 2016. LAAFS president Baiba Rivža reported on developments in the projects ICE and SUMFOREST and work in the project 4D4F. The latest developments in respect to contests in which members of the LAS DAFS and the LAAFS would participate as judges and organisers were discussed as well. In cooperation with the MoA, ALTUM, and LUA, members of the LAS DAFS participated in the following contests: a contest "Sējejs", held by the MoA, in the section "Science for Rural Development", a contest for the prize named after J. Lielmanis, a contest for young scientists "Harvest Festival", a contest for the prize named after Pauls Lejiňs, held by the LAS and the LAAFS, and a contest for young scientists, held by the LAS.

10 June - the general meeting of the LAAFS was held, in which the members of the LAS DAFS and the LAAFS took part. LAS Full Member Baiba Rivža introduced the participants to the work done by the LAAFS and the LAS DAFS in research and in popularising science, the achievements made during the year, the success and new challenges. At the general meeting, presenters came up with valuable proposals on agriculture, the bioeconomy, forestry, and food production technologies. LUA rector Dr.oec. Irina Pilvere reported on opportunities for the development of the bioeconomy in Latvia. The deputy director of Latvian State Forest Research Institute "Silava", Dr.silv. Jurğis Jansons, familiarised the audience with the development of knowledge-based forestry and the work done by Latvian forestry scientists in relation to sustainable forestry. A new LUA doctor of engineering science and a winner of the prize of the LAAFS, LUA, and JSC Development Finance Institution Altum, Dr.sc.ing. Laila Vilmane, reported on research on gluten-free flour and its products.

The LAS general secretary, LAS Full Member Andrejs Siliņš, and the foreign member of the LAAFS, Professor Jonas Jasaitis (Siauliai University), made welcome addresses to the participants of the LAAFS general meeting.

29 September - a corresponding member candidate of the LAS, Dr.sc.ing Uǵis Cābulis whose scientific activity is associated with the Latvia State Institute of Wood Chemistry, 
reported at the meeting. The candidate familiarised the audience with his long-term work and achievements in research on polymers from renewable sources. A participant of the LAAFS contest for young scientists "Harvest Festival", Mg.agr. Baiba Lāce, reported on her "Investigation into Pear - Juniper Rust (ier. Gymnosporangium sabinae (Dicks.) G. Winter) in Latvia". A candidate for the Pauls Lejiņš Prize, Dr.agr. Dainis Lapiņš, reported as well. The professor presented a set of research works "Opportunities for Scientifically Justified Optimisation Technologies for Field Crops". Pauls Lejiņš Prize is awarded to individual scientists for their fundamental research that has significantly contributed to the development of rural areas in Latvia. The chairperson of the Division, LAS Full Member Baiba Rivža acquainted the audience with plans for a forum "Smart Growth. Challenges and Solutions" to be held under the National Research Programme EKOSOC-LV in the autumn of 2016, as well as the latest developments in the projects ICE, 4D4F, and Sumforest.

31 October - a joint meeting of the LAS DAFS and the LAAFS presidium, in which a candidate for a corresponding member of the LAS, Dr.sc.ing. Sandra MuižnieceBrasava, reported on "Contribution of Cooperation between the Latvia University of Agriculture Scientists and Entrepreneurs to the National Economy of Latvia in the Field of Food Production". A participant of the LAAFS contest for young scientists and doctoral students "Harvest Festival 2016", Mg.agr. Laila Dubova, reported as well. Her research focused on factors determining the productivity of faba beans (Vicia faba L.). At the end of the meeting, greet- ings were made to LAS Full Member Edìte Kaufmane, on her birthday, and to a winner of the MoA contest "Sējējs-2016", LAS Full Member Baiba Rivža.

28 November - a joint meeting of the LAS DAFS and the LAAFS presidium summarised the work done during the year. Newly elected corresponding members of the Division - Dr.sc.ing. Sandra Muižniece-Brasava and Dr.sc.ing. Uǵis Cābulis — were greeted in a formal atmosphere. A newly elected foreign member of the Division, Dr.habil.agr. Zenonas Dabkevičius, was sent an invitation to visit Latvia and take part in the ceremony of giving LAS diplomas. The meeting had a small exposition of products developed by the LUA Food Technology Faculty and the LUA Institute of Horticulture, which were created in cooperation with entrepreneurs. Among the products, there were the flakes "MILZU!", the apple chips "Garden Snack", children puree "Rūdolfs", the bee bread "BEE BITE ", etc. Participants of a contest jointly held by JSC Development Finance Institution Altum and the LAAFS, young scientists — Dr.agr. Līga Vilka and Mg. Lāsma Aḷeksējeva — whose work was recognised as a considerable contribution to research on rural development, presented their findings.

Dr.agr. Līga Vilka reported on "Cranberry Fruit Rot and its Agents in Latvia”, while $M g$. Lāsma Aḷeksējeva reported on "Innovation Development Potential in Organic Farming in Latvia". Both reports aroused the interest of the audience and prompted scientific discussion, and the young scientists gave professional and pithy answers to the questions asked by the audience. 